\title{
The Impact of Institutional Ownership and a Firm's Size on Firm Value: Tax Avoidance as a Moderating Variable
}

\author{
Vince Ratnawati ${ }^{1^{*}}$, Azhari.S ${ }^{2}$, Desmond Freddy ${ }^{3}$, Nita Wahyuni ${ }^{4}$ \\ ${ }^{1}$ Economic Faculty, Universitas Riau, Pekanbaru, Indonesia \\ ${ }^{2}$ Economic Faculty, Universitas Riau, Pekanbaru, Indonesia \\ ${ }^{3}$ Economic Faculty, Universitas Riau, Pekanbaru, Indonesia \\ ${ }^{4}$ Economic Faculty, Universitas Riau, Pekanbaru, Indonesia
}

\section{ABSTRACT}

Objective - The objective of this study is to investigate how institutional ownership and firm size affect firm value. The study also investigates the moderating effect of tax avoidance on the relationship between institutional ownership and the size of a firm on its value.

Methodology/Technique -A model was developed and tested using a sample of 66 manufacturing companies listed on the Indonesian Stock Exchange between 2012 and 2014.

Findings - The data was collected and analysed using a least square regression and moderated regression analysis. The analysis shows that institutional ownership and firm size affect firm value. The results also indicate that tax avoidance moderates the effect of institutional ownership and that of a firm's size on its value.

Type of Paper: Empirical.

Keywords: Institutional Ownership, Firm Size, Tax Avoidance, Firm Value.

JEL Classification: G30, G32, G39.

\section{Introduction}

The credibility and prosperity of the owner of a firm is reflected in the value of a firm; therefore, the a firm must improve or at least maintain its value to encourage investments in order to maintain the sustainability of the firm. A higher value indicates higher credibility for the company and also implies good health of the owner (Wahyudi and Parwestri, 2006). According to Allen and Philips (2000), a company's financial performance will have an impact on the amount of investors choosing to buy shares in that firm.

\footnotetext{
* Paper Info: Received: February 12, 2018

Accepted: March 31, 2018

* Corresponding author: Vince Ratnawati

E-mail: vincefile28@gmail.com

Affiliation: Economic Faculty, Universitas Riau, Pekanbaru, Indonesia
} 
Therefore, management will undertake various efforts to increase the firm's value. Corporate governance is a tool that may help the chief executive officer [CEO] to increase a firm's value, as it can be used to control outgoing costs, which may lead to an increase in the firm's overall value. According to Jensen and Meckling (1976), institutional ownership is one such corporate governance mechanism that can reduce an agency's conflict problems.

According to some researchers, institutional ownership is thought to have an effect a company's performance as a result of the controls that the firm implements on its owners (Nuraina, 2012). A firm's size can also be an indicator of its development. Large companies will be able to access capital markets more readily, thereby allowing the company to have the ability and flexibility to raise funds, a condition perceived by investors as a positive signal for investment. The size of a firm is also a positive reflection of a firm's value (Nuraina, 2012). Currently in Indonesia, tax revenues are still not in accordance with the specified targets. Meanwhile, the current state revenues are largely sourced from taxes, a situation that is predominantly the result of tax avoidance practices. Saifudin and Yuanda (2016) state that tax avoidance by manufacturing companies listed on the Indonesian Stock Exchange has increased every year bettween 2011 and 2014. In 2012, the average ETR [Effective Tax Rate] increased by 0.02 units from the previous year; in 2013, to 0.270 ; and in 2014, to 0.271 . This condition appears to be an indication that the tax-avoidance phenomenon still increases from year to year.

\section{Literature Review}

Institutional investors are sophisticated, and hence are better able to manipulate stock market information to predict earnings, a condition that will affect the increase in a firm's value. According to the Agency Theory developed by Jensen \& Meckling (1976), agency relations arise when the executive officer delegates authority to an agent to provide a service. Differences in the interests of managers (agents) and shareholders (executive officers) may cause agency problems, which can lead to non-achievement of corporate objectives in increasing a firm's value. The percentage of shares owned by the institution may affect things such as the process of preparing financial statements, in which there is no possibility of the accrual in the interest of the management (Gideon, 2005). Thus the existence of institutional investors may reduce intra-agency conflict and can therefore increase the firm's value. Herawati (2008), Nuraina (2012), and Wida and Suartana (2014) all found that institutional ownership has an effect on firm value. Further, Cornet et al. (2008) concludes that corporate oversight by institutional investors may encourage managers to focus more on the company's performance, thereby reducing opportunistic or self-serving behaviour. These findings indicate that high institutional ownership will increase firm value.

Saxena (2009 in Mule et al., 2015) asserts that large companies should try to optimise they way in which they deal with market risk and uncertainty to have a better chance of dealing with losses. Companies with larger assets tend to be better able to generate profits compared to companies with smaller assets (Dewinta and Setiawan, 2016). Thus, companies with large profits will have greater stability in their operation. Further, firm size (which is proxied by its total assets) is indicative of the development of the company, which in turn can impact the improvement of the company's market performance. A relatively larger market share is reflective of a firm's competitiveness.

Tax avoidance is a minimisation strategy undertaken by taxpayers legally and in accordance with the provisions of tax laws using methods and techniques to take advantage of the weaknesses contained within the laws and regulations, to reduce the amount of tax actually paid (Pohan, 2015: 23). Tax avoidance behaviour by managers tends to decrease form value, as investors assume that low profits will result in low stock returns. Santa and Regende (2016) found that tax avoidance has a negative effect o firm value. Another study conducted by Chen et al. (2014) found that tax avoidance behaviour increases agency costs and reduces firm value. However, Chen, Kee, and Rasiah (2016) identified an indirect relationship between tax avoidance 
and market value as a proxy o firm value; whereas, Desai and Dharmapala (2009) found that tax avoidance activity by firms does not increase firm value.

As discussed earlier, institutional ownership will affect a firm's value; i.e., the greater the institutional ownership, the higher the firm's value. Aina (2016) found that tax avoidance will decrease a firm's value. Large and stable firms tend to be more inclined to engage in tax avoidance. This occurs because, in general, stable and large companies tend to earn large profits, which in turn increases their tax burden. This phenomenon triggers the desire of large companies to engage in tax avoidance. Darmawan (2014) and Swingly (2015) found that firm size has a positive effect on tax avoidance, however, Praditasari and Setiawan (2017) found that institutional ownership and firm size have a negative effect on tax avoidance, which they hypothesised as follows:

H1: Institutional ownership affects firm value.

H2: Firm size affects firm value.

H3: Tax avoidance moderates the effect of institutional ownership on firm value.

H4: Tax avoidance moderates the effect of firm size on firm value.

\section{Research Methodology}

\subsection{Population and Sample}

The population of the study consists of manufacturing companies listed on the Indonesian Stock Exchange between 2012 and 2014. From that population, a total of 66 companies were selected as a qualified sample. After screening based on the criteria listed in Table 3.1, the final sample size was 198 observation-years, as shown in the detailed list in Table 3.1.

Table 3.1. Sample Description

\begin{tabular}{ll}
\hline Manufacturing companies listed, 2012-2014 & 144 \\
Incomplete data & 78 \\
Qualified samples & 66 \\
Total observation-years & $3 * 66=198$ \\
\hline
\end{tabular}

\subsection{Measurement of Firm Value}

Firm Value is measured by using Tobin's Q, which was also used by Desai and Dharmapala (2009).

Tobin's $\mathrm{Q}=: \frac{\text { MVE+DEBT }}{\mathrm{TA}}$

Where:

MVE = closing stock price $\mathrm{x}$ outstanding shares

DEBT = current liabilities + long-term liabilities

$\mathrm{TA}=$ Book value of total assets 
Institutional ownership $=\%$ institutional ownership in the company (Ratnawati and Ali, 2015).

Firm Size $\quad=$ is defined as the natural $\log (\ln )$ of total assets (Hasan et al., 2012;

Mansor, Ahmad Zaluki and Osman, 2013).

Tax Avoidance = Cash Effective Tax Rates (Cash_ETR), which as developed by Dyreng et al.

(2008).

$$
\text { Cash_ETR }=\frac{\Sigma \text { CashTaxPaid }}{\Sigma \text { PretaxIncome }} \times 100 \%
$$

\subsection{Analytical Techniques}

The hypothesis testing was conducted using multiple regression models, as stated below:

Hypothesis 1 and 2: FV $=\alpha+\beta 1$ InsOwn $+\beta 2 \mathrm{FSz}+\varepsilon$

Hypothesis 3: FV $=\alpha+\beta 1$ InsOwn $+\beta 2$ InstOwn*TxAv $+\varepsilon$

Hypothesis 4: $\mathrm{FV}=\alpha+\beta 1 \mathrm{FSz}+\beta 2 \mathrm{FSz} * \mathrm{TxAv}+\varepsilon$

Where $\quad$ FV = Firm Value

InstOwn = Institutional ownership

$\mathrm{FSz} \quad=$ Firm Size

TAv $\quad=$ Tax Avoidance

\subsubsection{Normality Testing}

The normal distribution of data was obtained by using normal probability plot analysis. The normality test results indicated that the points are spread around a diagonal line, and the distribution follows the direction of the diagonal line, thereby indicating that the data meets the normality assumption.

\subsubsection{Multicollinearity Testing}

To determine whether there is autocorrelation, multicollinearity testing was conducted to obtain the Variance Inflation Factor (VIF) value of each independent variable, as listed below in Table 3.4.1.

Table 3.4.1 Regression Results

\begin{tabular}{|c|c|c|c|}
\hline Model & Collinearity Statistics Tolerance & VIF & P Value \\
\hline InstOwn & 0.682 & 1.466 & 0.026 \\
\hline Firm Size & 0.929 & 1.076 & 0.003 \\
\hline InsTav & 0.294 & 3.401 & 0.006 \\
\hline FSizeTav & 0.278 & 3.602 & 0.002 \\
\hline
\end{tabular}


Dependent Variable: Firm Value (Y)

Table 3.4.1 indicates that all the independent variables have a tolerance value $>0.10$ and VIF $<10$. Therefore, it can be concluded that the independent variables used in the regression model of this research are free from the problem of multicollinearity (Gozali, 2013).

\subsubsection{Autocorrelation Testing}

To determine whether there is autocorrelation can be ascertained from the DW [Durbin-Watson] value calculated for each variable, as listed in Table 3.2 below. The DW value of 1.761 and the value range between the values DW -2 to +2 , indicate that there is no autocorrelation (Gozali, 2013). Hence, there is no problem of autocorrelation in the regression model of this study.

Table 3.4.2 Model Summary

\begin{tabular}{crrrrr} 
Model & R & R Square & Adj R Square & F Change & Durbin-Watson \\
\hline 1 & $0.27 \mathrm{a}$ & 0.077 & 0.061 & 4.996 & 1.788 \\
\hline
\end{tabular}

\subsubsection{Heteroscedasticity Testing}

The scatterplot in Figure 1 demonstrates that the points on the image do not form a specific pattern, and the data is spread above and below the numeral 0 on the Y-axis. This plot indicates that the model does not exhibit heteroscedasticity, which means that the sample variance of the observation residuals to other observations are in common and can be said to be efficient. Therefore, on the basis of the assumptions of the classical test results indicating that the model is free of autocorrelation, multicollinearity, and heteroscedasticity, this model is fit for use in this study.

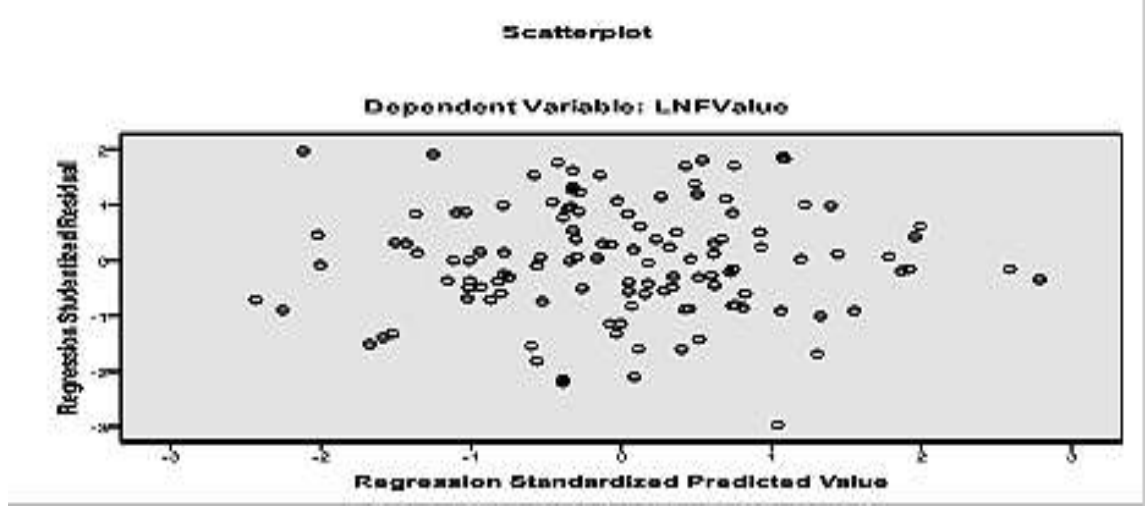

Figure 1. Heteroscedasticity Test Results 


\section{Results}

On the basis of Table 3.4.1, it can be observed that the $\mathrm{P}$ values of institutional ownership and firm size, respectively, have positive values of 0.026 and 0.003 , which are smaller than 0.05 . Therefore, it can be concluded that both institutional ownership and firm size affect firm value. That table also indicates that the values of InsTav and FsizeTav, being 0.006 and 0.002 respectively, are both smaller than 0.05 . This demonstrates that tax avoidance moderates the effects of institutional ownership and firm size on firm value.

\section{Discussion}

\subsection{Institutional Ownership, Firm Size and Firm Value}

The results show that the higher the institutional ownership and size of a firm, the higher the value of the firm, also indicating that institutional ownership is capable of effectively controlling management. Such control is implemented through effective monitoring so that it will impact the increased credibility of the company, followed by a decrease in the tendency toward dysfunctional behaviour. These conditions will of course affect the increase in a firm's value. This finding is consistent with the findings of Dechow et al. (1996), who states that high institutional ownership is followed by an increase in the credibility of the company's financial statements.

Gideon (2005) also found that a certain percentage of shares owned by the institution could affect the process of preparing financial statements, which does not rule out any accrualisation in the interest of the management. Generally, institutional investors are sophisticated, hence, they will become more capable of using current information to predict future earnings, in comparison with non-institutional investors. This finding is also consistent with Herawati (2008), Nuraina (2012), and Wida and Suartana (2014). These findings indicate that high institutional ownership will impact the increasing value of a firm. Other findings by Gillian and Starks (2003) and Cornett et al. (2008) reveal empirical evidence that controls by institutional investors may limit a manager's dysfunctional behaviour, which results in a decrease in a firm's value.

Meanwhile, Cornet et al. (2008) suggests that control of a firm by an institutional investor can encourage managers to focus more attention toward the company's performance in order to reduce opportunistic or self-serving behaviour, which will ultimately have an impact on improving firm value. Gill and Obradovich (2012), Prasetyorini (2013), and Pratama and Wiksuana (2016) also found that a firm's size has a positive influence on the firm's value.

Thus, a larger sized firm will have a higher overall value. According to Saxena (2009), in Mule et al. (2015), a large corporation will be able to discover better and more meaningful ways to avoid market risk and uncertainty and also have a better chance of avoiding losses. According to Dewinta and Setiawan (2015), companies that have large assets tend to be more capable of generating profits than companies with smaller total assets. A firm's size proxies by total assets represent the development of the company, which can trigger a positive response that impacts the company's market performance. Therefore, a relatively larger market share reflects the high competitiveness of a company.

\subsection{The Moderating Role of Tax Avoidance}

The test results from moderated regression analysis show that tax avoidance acts as a variable that moderates the influences between institutional ownership and a firm's size on the firm's value. Negative beta values indicate that tax avoidance weakens the effects between both institutional ownership on a firm's value and the size of a firm on its value. The occurrence of tax avoidance in companies will further weaken the influence of institutional ownership on the firm's value. The test results also indicate that higher institutional 
ownership will lead to a higher value for a company. The phenomenon of tax avoidance will reduce the strong influence of institutional ownership in increasing the value of a firm.

Tax avoidance behaviour by managers tends to lead to a decrease in a firm's value, caused by small profits as a direct result. Further, low earnings will result in low stock returns, followed by a negative outlook from investors. This condition will affect a decline in stock prices and also ultimately result in a decline in corporate value. According to Armstrong et al. (2010), if a company avoids taxes by poor governance, the firm poses the risk of a conflict of interest, which will in turn trigger an opportunity for managers to divert costs toward their personal interests. Tax avoidance may also have an impact on the value of the company. According to Aina (2016), tax avoidance will reduce the value of a firm.

The results from hypothesis testing to measure the effect of a firm's size on its value indicate that size will indeed affect value. A positive beta value indicates that the larger the size of a firm, the higher the firm's value. However, large companies tend to practice tax avoidance to minimize remittances due. Thus, further tax avoidance will reduce a firm's value.

Testing of the role of tax avoidance as a variable moderating the effect of a firm's size on its value resulted in a significant $\mathrm{P}$ value, as well as a beta value, which was negative. Therefore, it has been demonstrated that the practice of tax avoidance weakens the influence of a firm's size on its value. Hence, a company will thereby reduce the role of size in affecting corporate value.

\section{Conclusion}

The results show that both institutional ownership and firm size have a positive influence on the value of the firm. These results imply that institutional investors are sophisticated individuals who exercise expert corporate control. The findings also indicate that larger firms will have an impact on higher values of such firms, because they are more stable in their operations, which has a positive impact on the value of a firm. This study also shows that tax avoidance weakens the influence of both institutional ownership and the size of a firm on its value. Thus, tax avoidance practices result in a reduction in the value of a firm. The results of this study may assist institutions such as those on the Indonesian Stock Exchange, as well as individual investors, to better understand how institutional ownership and firm size can affect firm value. Moreover, from a theoretical perspective, these findings may provide a clearer and broader understanding of Agency Theory.

\section{References}

Allen, J. W., \& Phillips, G. M. (2000). Corporate equity ownership, strategic alliances, and product market relationships. The Journal of Finance, 55(6), 2791-2815.

Ratnawati, V., Freddy, D., \& Hardi, H. (2018). Ownership Structure, Tax Avoidance and Firm Performance. Archives of Business Research, 6(1).

Armstrong, C. S., Guay, W. R., \& Weber, J. P. (2010). The role of information and financial reporting in corporate governance and debt contracting. Journal of Accounting and Economics, 50(2-3), 179-234.

Zhang, C., Cheong, K. C., \& Rasiah, R. (2017). Corporate Tax Avoidance and Performance: Evidence from China's Listed Companies. Institutions and Economies, 61-83.

Cornett, M. M., Marcus, A. J., \& Tehranian, H. (2008). Corporate governance and pay-for-performance: The impact of earnings management. Journal of financial economics, 87(2), 357-373.

Darmawan, I. G. H., \& Sukartha, I. M. (2014). Effect of Corporate Governance, Leverage, Roa, and Company Size Implementation on Tax Avoidance. E-Journal of Accounting, 143-161.

Dechow, P. M., Sloan, R. G., \& Sweeney, A. P. (1996). Causes and consequences of earnings manipulation: An analysis of firms subject to enforcement actions by the SEC. Contemporary accounting research, 13(1), 1-36.

Desai, M. A., \& Dharmapala, D. (2009). Corporate tax avoidance and firm value. The review of Economics and Statistics, 91(3), 537-546.

Dewinta, Ida Ayu Rosa dan Putu Ery Setiawan. (2016). The Impact of Firm Size, Firm Age, Profitability, Leverage, and Sales Growth on Tax Avoidance. E-Journal Akuntansi Universitas Udayana, 14 (3): 1584-1613. 
Dyreng, S. D., Hanlon, M., \& Maydew, E. L. (2008). Long-run corporate tax avoidance. the accounting review, 83(1), 61-82.

Boediono, G. S. (2005). Quality of profit: Study the effect of corporate governance mechanisms and the impact of earnings management using path analysis. National Symposium on Accounting VIII, 9, 175-194.

Gillan, S., \& Starks, L. (2003). Corporate governance, corporate ownership, and the role of institutional investors: A global perspective.

Obradovich, J., \& Gill, A. (2013). The impact of corporate governance and financial leverage on the value of American firms.

Gozali, I. (2013). Aplikasi Analisis Multivariate dengan Program IBM SPSS 21 Update PLS Regresi, Edisi 7. Badan Penerbit Universitas Diponegoro. Semarang.

Hassan, S. U., \& Ahmed, A. (2012). Corporate governance, earnings management and financial performance: A case of Nigerian manufacturing firms. American International Journal of Contemporary Research, 2(7), 214-226.

Herawaty, V. (2008). The role of corporate governance practice as a moderating variable of effect of earnings management on firm value. Journal of Accounting and Finance, 10(2), 97-108.

Jensen, M. C., \& Meckling, W. H. (1976). Theory of the firm: Managerial behavior, agency costs and ownership structure. Journal of financial economics, 3(4), 305-360.

Mansor, N., Che-Ahmad, A., Ahmad-Zaluki, N. A., \& Osman, A. H. (2013). Corporate governance and earnings management: A study on the Malaysian family and non-family owned PLCs. Procedia Economics and Finance, 7, 221229.

Mule, R. K., Mukras, M. S., \& Nzioka, O. M. (2015). Corporate size, profitability and market value: An econometric panel analysis of listed firms in Kenya. European Scientific Journal, ESJ, 11(13).

Nuraina, Eva. (2012). The effect institutional ownership and firm size on debt policy and firm value (Study on manufactured company which is listed on Indonesian Stock Exchange). Jurnal Bisnis dan Ekonomi (JBE),9 (2) : 110125

Pohan, C. A. (2013). Tax Management and Tax Planning Business Management. Gramedia Pustaka Utama, Jakarta.

Prasetyorini, Bhekti Fitri. (2013). The effect of firm size, leverage, price earning ratio and Profitability on firm value. Jurnal Ilmu Manajemen, 1(1), h: 183-196.

Praditasari, Ni Koming Ayu., Putu Ery Setiawan. (2017). The effect of good corporate governace, firm size, leverage, and profitability on firm size. E Jurnal Akuntansi Universitas Udayana. 19(2):1229-1258

Pratama, I Gusti bagus Angga, I Gusti Bagus Wiksuana. (2016). The effect of firm size and leverage on firm value with profitability as a mediating variable. E- Jurnal Manajemen UNUD, 5 (2):1338-1367

Ratnawati, V., \& Hamid, M. A. A. (2017). The moderating effect of managerial ownership and institutional ownership on the relationship between control right and earnings management. Australian Academy of Accounting and Finance Review, 1(1), 69-85.

Saifudin., Derik Yuanda. (2016.) Determinant of return on asset, leverage, firm size, fiscall loss compensation and institutional ownership on tax avoidance (Empirical study on manufactured company which listed on Indonesian Stock Exchange from 2011 - 2014). Jurnal Penelitian Ilmu Ekonomi WIGA 6 (2); 131 - 143

Leite Santa, S. L., \& Rezende, A. J. (2016). Corporate tax avoidance and firm value: from Brazil. Revista Contemporânea de Contabilidade, 13(30).

Dyreng, S. D., Hanlon, M., \& Maydew, E. L. (2008). Long-run corporate tax avoidance. the accounting review, 83(1), 61-82.

Sudianto, Bambang., Elen Puspitasari. (2010). Tobin's Q and Alman-Z Score as the indicator of firm performance measuremet. Accounting Review, 2: 9-21

Wahyudi and Perwestri, Hartini.P. (2006). The implication of ownership structures on firm value, the financial decision as a intervening variable. SNA IX: Ikantan Akuntan Indonesia

Wida,Ni Putu., I Wayan Suartana. (2014). The effect of managerial ownership and institutional ownership on firm value. E-Jurnal Akuntansi Udayana 9(3): 575-590

Chen, X., Hu, N., Wang, X., \& Tang, X. (2014). Tax avoidance and firm value: evidence from China. Nankai Business Review International, 5(1), 25-42. 